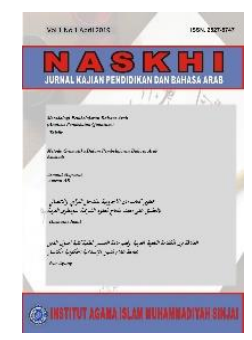

\title{
NASKHI
}

Jurnal Kajian Pendidikan dan Bahasa Arab

Volume 3, No. 1, 2021

ISSN (print) : 2527-5747

ISSN (online) : 2716-3369

Homepage : $\underline{\text { https://journal.iaimsinjai.ac.id/index.php/naskhi }}$

\section{KREATIFITAS GURU MATA PELAJARAN BAHASA ARAB DALAM MENINGKATKAN KEAKTIFAN BELAJAR SISWA KELAS XI MA NUHIYAH PAMBUSUANG KECAMATAN BALANIPA KABUPATEN POLEWALI MANDAR PADA MASA PANDEMI COVID-19}

\author{
Hamzah $^{1}$, Rahmat $\mathbf{R}^{2}$, Basri Mahmud ${ }^{3}$, Haeruddin ${ }^{4}$, \\ ${ }^{1}$ Institut Agama Islam DDI Polewali Mandar \\ ${ }^{2}$ Institut Agama Islam DDI Polewali Mandar \\ ${ }^{3}$ Institut Agama Islam DDI Polewali Mandar \\ ${ }^{4}$ Institut Agama Islam DDI Polewali Mandar \\ Korespondensi Penulis.E-mail:hamzah87_aziz@ymail.com Tlp.085253090687
}

\begin{abstract}
Abstrak
Penelitian ini bertujuan untuk mengetahui kreatifitas guru mata pelajaran Bahasa Arab dalam meningkatkan keaktifan belajar siswa kelas XI MA Nuhiyah Pambusuang pada masa pandemi Covid19 dan kendala yang dihadapi oleh guru mata pelajaran Bahasa Arab dalam meningkatkan keaktifan belajar siswa kelas XI MA Nuhiyah Pambusuang pada masa pandemi Covid-19. Penelitian ini termasuk penelitian lapangan berdasarkan tempat penelitiannya, dan berdasarkan datanya penelitian ini termasuk jenis penelitian deskriptif kualitatif. Adapun posisi peneliti dalam penelitian ini sebagai instrumen kunci yang dibantu dengan pedoman wawancara dan pengamatan dalam pengumpulan data. Dan teknik utama dalam pengumpulan datanya adalah melalui wawancara, pengamatan dan dokumentasi. Sedangkan dalam menganalisis data yang diperoleh peneliti menggunakan model analisis interaktif yang terdiri dari tiga prosedural setelah pengumpulan data yaitu reduksi data, penyajian data dan verifikasi data atau pengambilan kesimpulan. Adapun hasil penelitin ini adalah: Pertama; Usaha guru mata pelajaran Bahasa Arab dalam meningkatkan keaktifan belajar siswa kelas XI MA Nuhiyah Pambusuang adalah melalui: a) pembagian modul pelajaran secara tematik, $b$ ) pemberian tugas pekerjaan rumah, c) pemberian tugas media bergambar, dan d) pembentukan kelompok belajar untuk belajar di rumah guru. Kedua; Kendala yang dihadapi oleh guru mata pelajaran Bahasa Arab dalam meningkatkan keaktifan belajar siswa kelas XI MA Nuhiyah Pambusuang adalah: a) tidak semua siswa memiliki smartphone dan bisa mengakses aplikasi massenger, b) keaktifan siswa berkurang karena kegiatan siswa di rumah padat, c) siswa kurang bersemangat belajar secara daring, d) capaian pembelajaran tidak sesuai KKM Standar, dan e) mengukur dan mengharapakn efektifitas pembelajaran secara maksimal pada masa pandemi covid 19 mustahil adanya.
\end{abstract}

Kata Kunci: Kreatifitas Guru Bahasa Arab, Strategi Pembelajaran, Metode Pembelajaran, Teknik Pembelajaran 


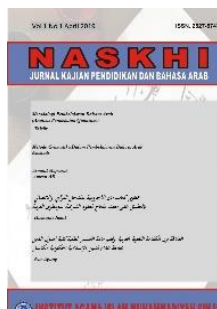

NASKHI

Jurnal Kajian Pendidikan dan Bahasa Arab

Volume 3, No. 1, 2021

ISSN (print) : 2527-5747

ISSN (online) : 2716-3369

Homepage : https://journal.iaimsinjai.ac.id/index.php/naskhi

\section{Pendahuluan}

Pembelajaran adalah proses interaksi peserta didik dengan pendidik dan sumber belajar pada suatu lingkungan belajar, baik lingkungan pendidikan formal maupun non formal. Kegiatan pembelajaran merupakan suatu kondisi yang sengaja diciptakan untuk membelajarkan peserta didik. Interaksi antara guru dan murid merupakan interaksi edukatif dengan memanfaatkan bahan ajar sebagai mediumnya. Tugas guru dalam inerkasi ini adalah memanfaatkan secara optimal input input yang ada untuk mencapai tujuan yang telah digariskan(Aziz Fachrurrazi, Erta Mahyuddin, 2018, hal. 51).

Dalam sebuah pembelajaran di kelas, guru tidak lagi menjadi satu-satunya sumber informasi dan sumber pengetahuan dengan menerapkan metode ceramah atau metode klasik lainnya tanpa ada aktifitas dan kegiatan interaktif antara guru dengan siswa. Sumber pengetahuan di era ini tidak lagi melulu dari seorang guru melainkan juga bisa dari siswa yang menjadi sumber pengetahuan, bahkan materi itu sendiri menjadi sumber informasi dan pengetahuan)Hamzah(2019 ‘. Sehingga klasifikasi strategi pembelajaran beragam berdasarkan tinjauannya, seperti berdasarkan fokus materi pembelajarannya terbagi menjadi tiga yaitu; strategi pembelajaran yang berpusat pada guru, strategi pembelajaran yang berpusat pada siswa dan strategi pembelajaran yang berpusat pada materi(Iskandarwassid, Dadang Sunendar, 2011, hal. 129).

Pembelajaran saat ini, seorang guru sangat diharapkan dan dituntut untuk berkreasi dan menciptakan inovasi pembelajaran dalam aktifitas belajar mengajarnya terkhusus dalam pembelajaran bahasa Arab yang sangat melibatkan keaktifan dan interaksi siswa dengan gurunya untuk meningkatkan kemahairan berbahasa peserta didiknya.

Proses belajar atau aktifitas belajar terjadi karena adanya interaksi antara siswa denganlingkungannya. Oleh karena itu, lingkungan perlu diatur sedemikian rupa sehingga timbul reaksi siswa ke arah perubahan perilaku yang diinginkan. Pengaturan lingkungan tersebut, meliputi analisis kebutuhan siswa, karakteristik siswa, perumusan tujuan, penentuan materi pelajaran, pemilihan strategi yang sesuai, serta media pembelajaran yang diperlukan.

Perbedaan karakter individu antar siswa dan kebutuhannya sudah menuntut adanya perbedaan strategi dalam menangani kebutuhan anak tersebut. Dalam hal ini, hal yang sangat dituntut dalam pembelajaran itu adalah agar bisa efektif dan efisien pembelajaran adalah strategi guru dalam menyampaikan materi dan mengolah kelas pembelajaran khususnya dalam pembelajaran bahasa.

Sejalan dengan hal tersebut di atas, Stern dan Stern mengutip pendapat klasik yang dikemukakan oleh Blumental dalam Pranowo bahwa diantara faktoryang memainkan peran dalam perkembangan bahasa anak adalah faktor internal maupun faktor eksternal(Pranowo, 2014, hal. 47).

Mulianto Sumardi menyatakan bahwa dalam pembelajaran bahasa yang menjadi tolak ukur kesuksesannya adalah penilaiannya pada segi metode yang digunakan oleh seorang guru sebab metodelah yang menentukan isi dan cara mengajarkan bahasa(Sumardi, 1975, hal. 7).

Sedangkan Chotibul Umam menyatakan bahwa keberhasilan pengajaran bahasa terutama bahasa Arab dipengaruhi oleh penggunaan sebuah pendekatan yang banyak menggunakan latihan atau drill karena bahasa adalah kemampuan. Kemampuan itu tidak bisa dicapai hanya dengan kaidah, tetapi dengan cara latihan dan melakukan pengulangan(Umam, 1980, hal. 43).

Uril Baharuddin seorang doktor Bahasa Arab UIN Maliki Malang mempertegas dalam bukunya dengan menyatakan bahwa posisi metode dalam sebuah pembelajaran itu 


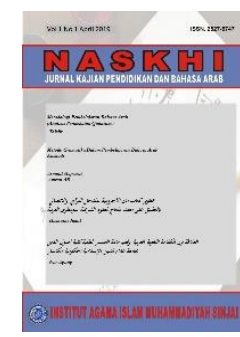

\section{NASKHI}

Jurnal Kajian Pendidikan dan Bahasa Arab

Volume 3, No. 1, 2021

ISSN (print) : 2527-5747

ISSN (online) : 2716-3369

Homepage : https://journal.iaimsinjai.ac.id/index.php/naskhi

sangat memiliki peran penting terlebih dalam mentransfer pengetahuan (materi ajar) karena suksesnya pembelajaran dari segi tercapainya tujuan pembelajaran yang diinginkan tergantung seberapa baik metode yang digunakan oleh seorang guru(Baharuddin, 2011, hal. 121).

Beberapa pendapat di atas menerangkan secara tersurat bahwa pentingnya mengatur sebuah lingkungan pembelajaran diantaranya dengan penggunaan strategi, metode dan teknik dalam sebuah pembelajaran agar terjadi interaksi yang baik antar guru dan siswa secara interaktif sehingga tujuan pembelajaran yang diinginkan bisa terealisasi secara efektif dan efisien.

Berdasarkan pemaparan tersebut di atas, maka peneliti mencoba untuk mengangkat tema penelitian yang berjudul "Kreatifitas Guru Mata Pelajaran Bahasa Arab dalam Meningkatkan Keaktifan Belajar Siswa Kelas XI MA Nuhiyah Pambusuang Kecamatan Balanipa Kabupaten Polewali Mandar Pada Masa Pandemi Covid 19”.

\section{Metode Penelitian}

Penelitian ini termasuk penelitian lapangan berdasarkan tempat penelitiannya, dan berdasarkan datanya penelitian ini termasuk jenis penelitian deskriptif kualitatif. Adapun posisi peneliti dalam penelitian ini sebagai instrumen kunci yang dibantu dengan pedoman wawancara dan pengamatan dalam pengumpulan data. Sedangkan teknik utama dalam pengumpulan data dalam penelitian ini adalah melalui wawancara, pengamatan dan dokumentasi. Untuk menganalisis data yang sudah diperoleh, peneliti menggunakan model analisis interaktif yang terdiri dari tiga prosedural setelah pengumpulan data yaitu reduksi data, penyajian data dan verifikasi data atau pengambilan kesimpulan.

\section{Hasil dan Pembahasan}

\subsection{Kreatifitas Guru Mata Pelajaran Bahasa Arab dalam Meningkatkan Keaktifan Belajar Siswa Kelas XI MA Nuhiyah Pambusuang}

Dalam dunia pendidikan, pandemi Covid-19 menjadi sebuah keniscayaan yang tidak mau tidak untuk diterima dan dilakoni dalam dunia pendidikan. Pandemi covid-19 menjadi perhatian khusus oleh pemerintah setempat khususnya di Indonesia untuk segala sektor dalam rangka memutus mata rantai penyebaran virus mematikan tersebut. Aktifitas paling rawan dan dihindari dalam perkembangan dan penyebaran virus covid-19 adalah berkerumun, sehingga aktifitas pembelajaran menjadi korban dalam rangka memutus mata rantai penyebarannya yang mengakibatkan libur tatap muka pembelajaran yang diganti dengan pertemuan pembelajaran secara virtual.

Indonesia yang beum siap untuk menghadapi hal tersebut khususnya di daerah pedalaman atau perkampungan yang jauh dari perkotaan, minim sarana dan prasarana pendukung, dan kurangnya SDM yang ahli di bidang IT membuat sibuk dan dadakan untuk secara terpaksa mengikuti panduan protokol pembelajaran di sekolah melalui jarak jauh secara daring, terlebih lagi adanya larangan dan surat edaran pemerintah terkait pemberlakuan pembelajaran secara daring di lembaga pendidikan(Mabruri, M., \& Hamzah, H., 2021). Sebagaimana intruksi Menteri Pendidikan dan Kebudayaan melalui Surat Edaran bernomor 36962/MPK.A/HK/2020 yang menerangkan tentang pembelajaran secara daring dan bekerja dari rumah (WFH) dalam rangka pencegahan penyebaran Covid-19 (https://www.kemdikbud.go.id/main/blog/, 2020). 


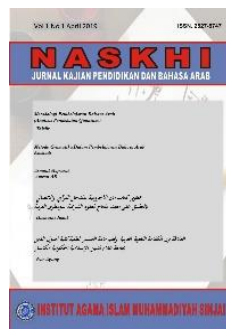

\section{NASKHI}

Jurnal Kajian Pendidikan dan Bahasa Arab

Volume 3, No. 1, 2021

ISSN (print) : 2527-5747

ISSN (online) : 2716-3369

Homepage : $\underline{\text { https://journal.iaimsinjai.ac.id/index.php/naskhi }}$

Atas hal tersebut, pendidik mata pelajaran bahasa Arab di MA Nuhiyah Pambusuang berusaha sebaik mungkin untuk/agar pembelajaran bahasa Arab tetap sampai kepada peserta didik, berjalan dan sesuai harapan mereka.

Dalam wawancara peneliti bersama guru mata pelajaran bahasa Arab MA Nuhiyah kelas XI Hamzah, S.Pd.I merasakan sebuah tantangan dalam mengajar karena kali pertama dan menjadi pengalaman pertama dibandingkan dengan pembelajaran sebelumnya yang bersifat luring (offline). Dalam penyampaiannya ia menuturkan:

"Tahun 2020 ini di semester ganjil menjadi tahun Corona yang merenggut aktifitas seorang pendidik yang sedianya mengajar di kelas bersama dengan perserta didiknya. Apa mau dikata tak ada yang menghendaki hadirnya pandemi ini membuat para guru di MA tanpa terkecuali saya (Hamzah, S.Pd.I) sebagai guru bahasa Arab peminatan tertantang, memutar otak dan mencoba segala cara yang sudah pernah dipelajari dengan memanfaatkan media aplikasi online untuk bisa peserta didik tetap belajar dan aktif dalam belajar" (Hamzah S. , Wawancara, 2020).

Begitupun dengan guru bahasa Arab lainnya yang mengajar di MA Nuhiyah Pambusuang yaitu Aradin, S.Pd.I yang ikut merasakan keprihatinan terhadap peserta didiknya karena sistem pembelajaran yang diterapkan adalah daring yang belum tentu peserta didiknya bisa mengakses semua sehingga ia pun mencoba mencari cara lain agar bisa peserta didiknya tetap belajar pada masa pandemi covid-19. Berikut penyampaian informan kepada peneliti saat mewawancarainya:

"pandemi covid-19 ini menjadi warna baru dan kebiasaan baru bagi kami di lembaga pendidikan yang menyampaikan pembelajaran secara daring dan ini sangat berat karena kami di desa sangat minim dengan sarana prasarana untuk melakukan pembelajaran daring. Kami pun merasa prihatin terhadap peserta didik kami yang belum tentu bisa mengakses semua sistem atau aplikasi yang digunakan karena orang dewasa saja sulit untuk menjalani demikian karena butuh kuota internet, terlebih peserta didik kami belum tentu bisa semuanya. Sehingga kadang kami menyiasati agar mereka bisa belajar dengan cara menyuruh datang ke rumah untuk belajar bersama secara luring (offline) sekali dalam sebulan, bahkan terkadang saya mencuri kesempatan setelah pembelajaran luring mata pelajaran matematika (yang kebetulan istri sebagai guru matematikanya) di rumah untuk sekalian memanfaatkan kehadiran para peserta didik untuk belajar"(Aradin, 2020).

Lebih lanjut dalam wawancara peneliti kepada para guru mata pelajaran bahasa Arab di MA Nuhiyah bahkan kepala Madrasah MA Nuhiyah (Ilham Sopu, S.S) saat ditanyakan aplikasi yang dijadikan media dalam pembelajaran daring oleh guru di MA Nuhiyah adalah via aplikasi massenger. Penggunaan aplikasi tersebut kata mereka karena sederhana, terjangkau dan bisa digunakan tanpa menggunkan kuota internet (offline).

"pembelajaran di tahun 2020 ini khususnya di semester ganjil ini sangat mahal karena mengharuskan daring yang tidak semua bisa melakukannya, namun di sekolah kami MA Nuhiyah para guru lebih menggunakan aplikasi massenger karena disamping terjangkau penggunaannya, sudah familiar karena boleh dikata semua yang memiliki akun facebook menggunakan massenger karena terintegrasi ke aplikasi facebook, juga bisa digunakan tanpa menggunakan kuota internet atau dengan kata lain bisa digunakan secara luring (offline)"(Ilham Sopu, 2020). 


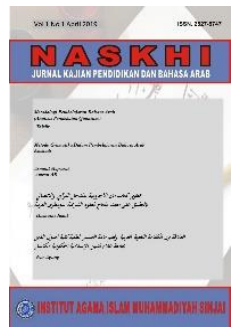

\section{NASKHI}

Jurnal Kajian Pendidikan dan Bahasa Arab

Volume 3, No. 1, 2021

ISSN (print) : 2527-5747

ISSN (online) : 2716-3369

Homepage : https://journal.iaimsinjai.ac.id/index.php/naskhi

Berikut di bawah ini upaya dan kreatifitas guru Bahasa Arab MA Nuhiyah Pambusuang dalam meningkatkan keaktifan dan belajar bahasa Arab peserta didik kelas XI MA Nuhiyah Pambusuang selama pandemi covid 19 sebagaimana dalam wawancara peneliti bersama dengan mereka di lapangan:

a. Membagikan modul pelajaran secara tematik

Dikarenakan sistem pembelajaran semester ganjil Tahun Pelajaran 2020-2021 ini secara daring, maka tatap muka diliburkan berdasarkan Surat Edaran Menteri Pendidikan dan Kebudayaan tentang pembelajaransecara daring dan bekerja dari rumah untuk mencegah penyebaran Covid-19. Sehingga para guru MA Nuhiyah Pambusuang melakukan pembelajaran melalui aplikasi massenger.

Sistim aplikasi massenger hanya bisa melakukan kirim pesan baik secara audio maupun visual sehingga komunikasi interaktif seperti fungsi pada aplikasi zoom, meet google ataupun whats app tidak bisa dialkukan pada aplikasi massenger. Sehingga guru mata pelajaran hanya bisa berkirim gambar materi, dan modul. Lebih dari pada itu menyampaikan perintah kepada peserta didik untuk menyalin dan menjawab soal atau pertanyaan sesuai yang tertuang di modul yang sudah dibagikan.

Kelebihan yang ada pada aplikasi massenger dibandingkan dengan aplikasi lainnya menurut para guru bahasa Arab MA Nuhiyah Pambusuang sesuai hasil wawancara dan petikan wawancara sebelumnya bahwa aplikasi massenger bisa digunakan dalam mode luring tanpa menggunakan kuota internet sehingga itu menjadi kemudahan bagi para guru bahasa Arab MA Nuhiyah Pambusuang.

b. Memberikan tugas pekerjaan rumah

Selain pembagian modul pelajaran kepada para peserta didik, juga para guru memberikan tugas pekerjaan rumah untuk bisa memantau perkembangan peserta didik dan mengevaluasi hasil pemahaman mereka.

Kata pak guru Hamzah, S.Pd.I sebagai guru mata pelajaran bahasa Arab peminatan di MA Nuhiyah Pambusuang dalam uraiannya bahwa pemberian tugas tau pekerjaan rumah menjadi satu-satunya cara yang ampuh untuk bisa diberikan tekanan pada peserta didik agar bisa aktif dalam belajar di masa pandemi covid ini, meskipun itu tak bisa dijamin kejujuran dari merek tapi itulah upaya yang bisa dilakukan karena keterbatasan ruang untuk bisa tatap muka.

c. Memberikan tugas media bergambar

Disamping tugas pekerjaan rumah untuk menjawab dan mengembangkan materi ajar, guru mata pelajaran bahasa Arab juga seperti Hamzah, S.Pd.I. menyiasati pemberian tugas kepada peserta didik agar tetap aktif dalam belajar dengan cara memberikan tugas pembuatan media bergambar seperti materi yang terkait dengan angka-angka untuk dibuat serapi mungkin kemudian dipres laminating agar kuat dan awet dan tugas tersebut menjadi media pembelajaran yang digunakan oleh gurunya.

d. Membentuk kelompok belajar untuk belajar di rumah guru

Sebagaimana disampaikan pada paragraf sebelumnya bahwa untuk mengupayakan agar para peserta didik tetap bisa belajar maka diusahakan membentuk kelompok belajar untuk belajar di rumah guru. Upaya ini sebagaimana yang dilakukan oleh pak guru Aradin, S.Pd.I guru bahasa Arab MA Nuhiyah Pambusuang karena melihat keprihatinan peserta didik mereka yang tidak semua bisa mengakses pembelajaran secara daring melalui aplikasi massenger karena keterbatasan alat. 


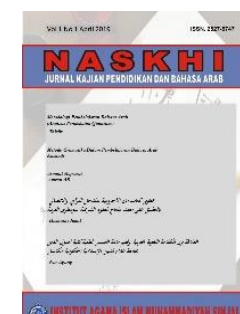

\section{NASKHI}

Jurnal Kajian Pendidikan dan Bahasa Arab

Volume 3, No. 1, 2021

ISSN (print) : 2527-5747

ISSN (online) : 2716-3369

Homepage : https://journal.iaimsinjai.ac.id/index.php/naskhi

\subsection{Kendala yang Dihadapi oleh Guru Mata Pelajaran Bahasa Arab dalam Meningkatkan Keaktifan Belajar Siswa Kelas XI MA Nuhiyah Pambusuang}

Pembelajaran bahasa Arab pada masa pandemi covid-19 meski bisa dijalankan dan membuat peserta didik tetap belajar namun dari pada itu, para guru bahasa Arab MA Nuhiyah Pambusuang mengalami kendala dan kesulitan yang dihadapi dalam meningkatkan keaktifan belajar siswa kelas XI MA Nuhiyah Pambusuang.

Di bawah ini beberapa uraian kendala yang disampaikan oleh para guru bahasa Arab MA Nuhiyah Pambusuang dalam wawancara peneliti bersama mereka:

a. Tidak semua siswa memiliki smartphone dan bisa mengakses aplikasi massenger

Pembelajaran daring yang diterapkan di MA Nuhiyah Pambusuang melalui aplikasi massenger tentu membutuhkan alat atau sarana yang bisa mendukung dan mengakses hal tersebut. Kendala pertama yang dihadapi oleh para guru dalam menjalankan pembelajaran daring adalah tidak semua peserta didik memiliki smartphone yang bisa mengakses aplikasi massenger.

Sehingga diantara upaya yang dilakukan oleh guru bahasa Arab MA Nuhiyah Pambusuang adalah melakukan pembelajaran luring dengan cara membentuk kelompok belajar yang dilakukan sekali sebulan di rumah guru tertentu.

b. Keaktifan siswa berkurang karena kegiatan siswa di rumah padat

Meskipun durasi waktu belajar daring sudah dipangkas $50 \%$ dari durasi waktu normal, namun yang menjadi kendala menurut sebagian guru mata pelajaran bahasa Arab Nuhiyah Pambusuang adalah tidak semua waktu peserta didik bisa digunakan karena kegiatan mereka di rumah padat, terlebih lagi smartphone yang digunakan adalah bukan milik pribadi peserta didik melainkan milik orang tua mereka yang notabene mereka juga butuhkan setiap harinya untuk kebutuhan komunikasi lainnya.

"waktu peserta didik pada masa pandemi covid ini susah sekali diminta, disamping karena kesibukan di rumah bersama orang tuanya juga smartphone yang digunakan bukan milik pribadi peserta didik tetapi milik orang tua yang mereka juga butuhkan untuk kebutuhan komunikasi lainnya"(Aradin, 2020).

\section{c. Siswa kurang bersemangat belajar secara daring}

Pembelajaran daring menjadi kebiasaan baru dan warna baru dalam kehidupan bersekolah peserta didik yang sangat jauh dari kebiasan normal sebelumnya yang penuh dengan riuh gembira tatap muka, ceria bersama penuh tawa di sekolah. Kebiasaan baru ini dikarenakan keterbatasan akses, sarana belajar secara daring, bersifat bebas dan kurang pengawasan sehingga menyebabkan peserta didik semangat belajarnya berkurang. Perasaan jenuh mereka dan semangat mereka dalam belajar nampak dari kehadiran keaktifan belajar mereka. dengannya:

Pak guru Hamzah, S.Pd.I menuturkan dalam hasil wawancara peneliti bersama

"pembelajaran daring ini sangat menyiksa rasanya karena kebiasaan baru dan sistem baru yang belum pernah kami laksanakan sebelumnya. Untuk mengontrol keaktifan peserta didik susah sekali selain melalui pemberian tugas. Guru saja merasa jenuh karena keterbatasan sarana, media dan alat pendukung lainnya, terlebih peserta didik terasa jenuh mereka sehingga semangat mereka dalam belajar kurang sekali yang bisa dilihat dari keaktifan dan kehadiran peserta didik saat belajar daring"(Hamzah S. , Wawancara, 2020). 


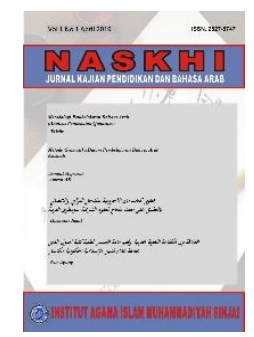

\section{NASKHI}

Jurnal Kajian Pendidikan dan Bahasa Arab

Volume 3, No. 1, 2021

ISSN (print) : 2527-5747

ISSN (online) : 2716-3369

Homepage : https://journal.iaimsinjai.ac.id/index.php/naskhi

d. Capaian pembelajaran tidak sesuai KKM Standar

Disamping kendala-kendala pembelajaran yang sudah disebutkan sebelumnya, guru bahasa Arab MA Nuhiyah Pambusuang juga menyampaikan dalam wawancara mereka dengan peneliti, bahwa keberhasilan, pemahaman dan serapan capaian pembelajaran KKM standar mata pelajaran bahasa Arab kali ini sangat jauh dari harapan.

"capaian keberhasilan peserta didik dalam memahami muatan inti mata pelajaran bahasa Arab kali ini sangat jauh dari harapan. Perbandingannya, jika semester kemarin bisa mencapai $75 \%$ pemahaman peserta didik terhadap inti pembelajaran maka untuk semester kali ini sangat jauh dari harapan yaitu 50\% pun tak bisa diperoleh, sangat miris dengan sistem yang diterapkan tahun ini yang membuat pukul rata sekolah seperti kami yang jauh dari perkotaan dan kurang lengkap sarana prasarana untuk diberlakukan"(Hamzah S. , Wawancara, 2020).

e. Mengukur dan mengharapakn efektifitas pembelajaran secara maksimal mustahil

Sistem pembelajaran pada masa pandemi covid-19 ini sangat memprihatinkan bila pemerintah setempat menginginkan hasil pembelajaran berjalan efektif dan efisien. Dan itu boleh dikata mustahil.

Rintihan guru bahasa Arab MA Nuhiyah Pambusuang melihat situasi dan kondisi pembelajaran saat ini sangat merasa dipusingkan karena juga menjadi pekerjaan rumah dan memutar otak mereka untuk bagaimana agar pembelajaran bisa maksimal dan efektif, juga agar peserta didik bisa belajar dengan baik penuh semangat seperti pada kondisi normal.

Kata mereka para guru bahasa Arab MA Nuhiyah Pambusuang dalam petikan wawancara peneliti dengan mereka:

"pembelajaran yang kami lakukan pada masa pandemi ini hanya bisa apa adanya tanpa ada apanya dikarenakan kebiasaan baru dengan kondisi serba dadakan, yang penting peserta didik bisa belajar, materi ajar sampai kepada mereka tanpa melihat efektifitasnya secara maksimal. Karena mengukur dan mengharapkan efektifitas pembelajaran sangat jauh dari harapan, bahkan kami sebagai lembaga pendidikan yang jauh dari perkotaan dengan sarana prasarana yang terbatas dan kurang sangat mustahil untuk mencapai efektifitas pembelajaran seperti yang terjadi di kota-kota besar dan ibu kota”(Hamzah S. d., 2020).

Menyelami perasaan dari petikan wawancara di atas bisa dirasakan bahwa sangat sulit untuk mencapai hasil pembelajaran secara maksimal pada masa pandemi covid-19 ini terlebih lagi mencari efektifitas dan efisiensi pembelajaran dengan serba keterbatasan dan kekurangan sarana dan prasarana yang mendukung.

Demikianlah hasil dan pembahasan yang bisa peneliti paparkan pada bab IV ini sebagai ujung dari perjalanan penelitian ini, dalam wawancara peneliti bersama para informan dan para guru bahasa Arab MA Nuhiyah Pambusuang ada satu poin pertanyaan khusus peneliti layangkan sebagai penutup, terkait dengan harapan para guru terhadap para pemangku jabatan baik di tingkat daerah maupun provinsi bahkan pusat yang menjadi rekomendasi penting kepada mereka. Dan kata mereka setelah melihat dan menjadi pengalaman pembelajaran pada masa pandemi covid-19 ini adalah:

"sebagai pendidik di lembaga pendidikan di daerah dengan niat baik dan tulus dalam rangka mencerdaskan kehidupan bangsa dan bernegara serta memanusiakan manusia, maka meminta kepada para pemangku jabatan di tingkat daerah maupun provinsi 


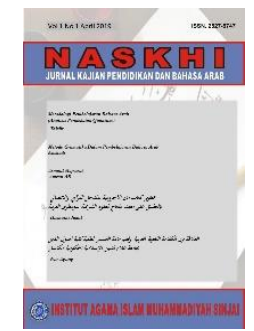

\section{NASKHI}

Jurnal Kajian Pendidikan dan Bahasa Arab

Volume 3, No. 1, 2021

ISSN (print) : 2527-5747

ISSN (online) : 2716-3369

Homepage : https://journal.iaimsinjai.ac.id/index.php/naskhi

bahkan pusat agar penerapan pembelajaran di daerah kami seperti di Pambusuang khususnya dan Kecamatan Balanipa Kabupaten Polewali Mandar secara umum untuk dibuka dan diberikan pembelajaran tatap muka. Dan sebagai bentuk kepedulian kami dalam bernegara untuk memutus mata rantai dan penyebaran covid-19 secara masiv maka tentu kami juga akan memberlakukan protokol kesehatan secara ketat karena kami juga sadar untuk tidak ingin merasakan dan terjangkit dengan yang namanya covid-19”(Hamzah S. d., 2020).

\section{Simpulan}

Sebagai penutup pada bagian ini, peneliti akan menyimpulkan dari hasil penelitian ini, sebagai berikut: 1) kreatifitas guru mata pelajaran Bahasa Arab dalam meningkatkan keaktifan belajar siswa kelas XI MA Nuhiyah Pambusuang adalah melalui: a) membagikan modul pelajaran secara tematik, b) memberikan tugas pekerjaan rumah, memberikan tugas media bergambar, dan membentuk kelompok belajar untuk belajar di rumah guru. 2) Kendala yang dihadapi oleh guru mata pelajaran Bahasa Arab dalam meningkatkan keaktifan belajar siswa kelas XI MA Nuhiyah Pambusuang adalah sebagai berikut: a) tidak semua siswa memiliki smartphone dan bisa mengakses aplikasi massenger,b) keaktifan siswa berkurang karena kegiatan siswa di rumah padat,c) Siswa kurang bersemangat belajar secara daring, d) capaian pembelajaran tidak sesuai KKM Standar, dan d) mengukur dan mengharapakn efektifitas pembelajaran secara maksimal pada masa pandemi covid ini mustahil adanya.

\section{Daftar Pustaka}

https://www.kemdikbud.go.id/main/blog/. (2020, 03 03). (Kementerian Pendidikan dan Kebudayaan) Dipetik 11 17, 2020, dari https://www.kemdikbud.go.id/: https://www.kemdikbud.go.id/main/blog/2020/03/se-mendikbud-pembelajaransecara-daring-dan-bekerja-dari-rumah-untuk-mencegah-penyebaran-covid19

Aradin, S. (2020, 11 18). Wawancara. (Haeruddin, Pewawancara)

Aziz Fachrurrazi, Erta Mahyuddin. (2018). Strategi Pembelajaran Bahasa Arab: Dari Prinsip Hingga Praktik. Malang: CV. Lisan Arabi.

Baharuddin, U. (2011). Maharat al-Tadris Nahwa I'dad Mudarris al-Lughah al-'Arabiyha alKaf'i. Malang: UIN-Maliki Press.

Hamzah. (2019). Learning Strategies for Arabic Grammar at Allo Biqar Pambusuang Foundation in Understanding the Heritage Books at Polewali Mandar, West Sulawesi. Malang: Diss. Universitas Islam Negeri Maulana Malik Ibrahim.

Hamzah, S. (2020, 11 16). Wawancara. (Haeruddin, Pewawancara)

Hamzah, S. (2020, 11 16). Wawancara. (Haeruddin, Pewawancara)

Hamzah, S. d. (2020, 11 16). Wawancara. (Haeruddin, Pewawancara) 


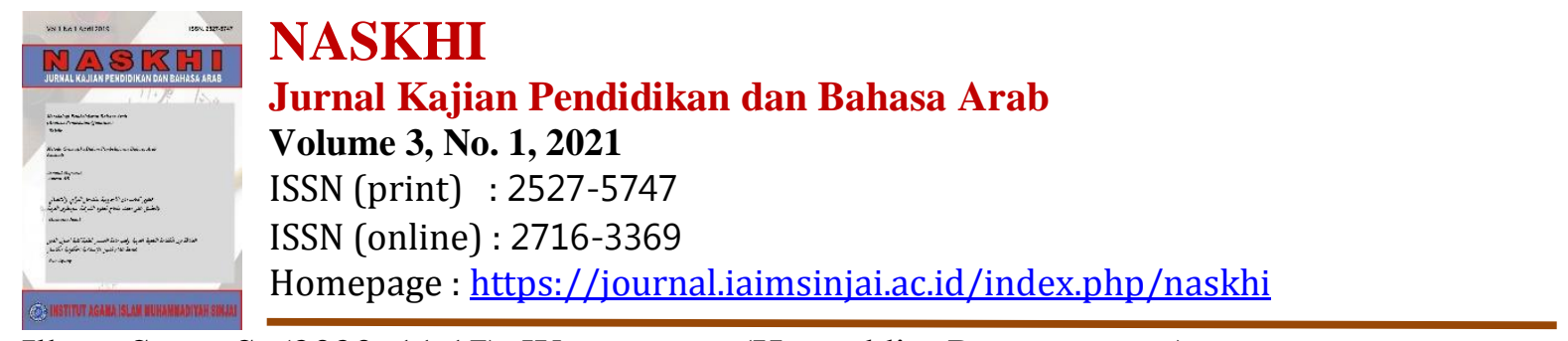

Ilham Sopu, S. (2020, 11 17). Wawancara. (Haeruddin, Pewawancara)

Iskandarwassid, Dadang Sunendar. (2011). Strategi Pembelajaran Bahasa. Bandung: Sekolah Pasca UPI kerjasama dengan PT Remaja Rosdakarya.

Mabruri, M., \& Hamzah, H. (2021). The Urgency of Using Internet-Based Arabic Learning Media in Online Learning in the Global Pandemic Era. Loghat Arabi: Jurnal Bahasa Arab dan Pendidikan Bahasa Arab, 1(2), 1-10.

Pranowo. (2014). Teori Belajar Bahasa; Untuk Guru Bahasa dan Mahasiswa Jurusan Bahasa. Yogyakarta: Pustaka Pelajar.

Sumardi, M. (1975). Pengajaran Bahasa Asing. Jakarta: Bulan Bintang.

Umam, C. (1980). Aspek-Aspek Fundamental dalam Mempelajari Bahasa Arab. Bandung: Al-Maarif. 